\title{
Cultivation of aerobic granular sludge in a microbial fuel cell
}

\author{
You-xian Gao and Ping Yang* \\ College of Architecture and Environment, Sichuan University, Chengdu 610065 Chengdu, China.
}

\begin{abstract}
Aerobic granular sludge(AGS) is a special biofilm formed by the self-aggregation of sludge material. In this study, AGS was cultivated in the biocathode of a continuous flow microbial fuel cell (MFC). During the formation of AGS, changes in sludge concentration, extracellular polymers (EPS), pollutants removal and power generation were examined. The results showed that, MLVSS kept above $5 \mathrm{~g} / \mathrm{L}$, the PS, PN and PN/PS of TB-EPS showed a gradually increasing trend, the removal efficiency of COD and ammonia nitrogen was $94.46 \%$ and $93.03 \%$, respectively. A maximum voltage output of $350 \mathrm{mV}$ was achieved.
\end{abstract}

\section{Introduction}

Aerobic granular sludge (AGS) is a special biofilm formed by cell self-aggregation under aerobic conditions [1]. As a new wastewater treatment technology, the advantages of large sludge volume and high organic load have great development potential in the treatment of domestic sewage and high-concentration organic wastewater [2,3]. At present, the formation conditions, formation mechanism, and pollutant removal performance of AGS are mainly carried out in sequential batch reactors with large aspect ratios $(H / D)[4,5]$. There are few reports on the cultivation of AGS in continuous flow reactors [6]. However, in actual wastewater treatment operations, continuous-flow operation of low-to-diameter ratio reactors are needed. Therefore, research on this type of reactor is needed for the popularization and application of AGS technology.

Microbial fuel cells (MFC) is a new technology that combines biological electricity generation and wastewater treatment [7]. MFC uses the catalytic action of electricityproducing microorganisms to directly convert chemical energy into electricity when treating the organic matter in wastewater. During the operation of MFC, the anode can generate protons and electrons. A large number of protons enter the cathode through the proton exchange membrane (PEM), which can neutralize the negative charge on the sludge surface and promotes the flocculation of flocculent sludge [8]. On the one hand, the biocathode can generate a certain shear force which promotes the cyclic movement of the sludge in the reactor, providing conditions for the formation of AGS. On the other hand, the cultivation of AGS in the continuous flow MFC cathode chamber can not only retain the electricity generation performance of the MFC, but also take advantage of the simultaneous nitrification and denitrification (SND) of AGS to promote the removal of pollutants [9]. Thus, it has great theoretical significance and practical value for optimizing the practical performance of MFC.

\section{Material and methods}

The reactor was made of plexiglass. It was divided into an anode chamber and a cathode chamber. The anode chamber was an anaerobic fluidized bed (AFB) with an effective volume of $10.66 \mathrm{~L}$, the cathode chamber was a biological cathode with an effective volume of $9.62 \mathrm{~L}$, and a precipitation zone with an effective volume of $3.81 \mathrm{~L}$ was provided. The two chambers were separated by a PEM and both anode and cathode electrodes were made of carbon paper (HCP030) and connected by copper wires. The external resistance was fixed at $1 \mathrm{k} \Omega$, and an UT70B multimeter was used to measure the output voltage.

Synthetic wastewater was used in this experiment, with glucose as the main carbon source and $\mathrm{NH}_{4} \mathrm{Cl}$ provided ammonia nitrogen and total nitrogen, $\mathrm{KH}_{2} \mathrm{PO}_{4}$ provided the phosphorus source, $\mathrm{NaHCO}_{3}$ controlled the $\mathrm{pH}$ value between 7.8-8.5. A small amount of trace elements (nutrient solution $1 \mathrm{~mL} / \mathrm{L}$, Table 1) were added to maintain microbial growth needs. And $300 \mathrm{mg} / \mathrm{L} \mathrm{CaCl}_{2}$ and $350 \mathrm{mg} / \mathrm{L} \mathrm{MgCl}_{2}$ was also added.

The anode sludge was composed of laboratory-grown anaerobic granular sludge, and the biocathode sludge was taken from the Chengdu Airport Wastewater Treatment Plant. In the start-up phase, $0.1 \mathrm{~L}$ of polymer carrier filler [10] and $4 \mathrm{~L}$ of mud-water mixed solution was added to the aerobic tank, and $8 \mathrm{~L}$ of tap water was added to fill the reactor simultaneously.

After two days of sulking, the anode and cathode began to enter water separately. HRT was $24 \mathrm{~h}$. The COD concentration in the anodic influent was $2500 \mathrm{mg} / \mathrm{L}$, while the $\mathrm{NH}_{4}{ }^{+}-\mathrm{N}$ concentration was $62 \mathrm{mg} / \mathrm{L}$, and the ratio of nitrogen to phosphorus was maintained at 5:1. The COD concentration of cathodic influent was $1500 \mathrm{mg} / \mathrm{L}$, the $\mathrm{NH}_{4}{ }^{+}$- $\mathrm{N}$ concentration of influent was $60 \mathrm{mg} / \mathrm{L}$, and the ratio of nitrogen to phosphorus was maintained at 5:1. After the anode and cathode effluent remained stable, the anode and cathode effluents were combined, and the anode

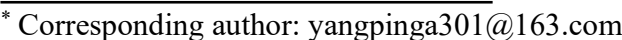


effluent flows into the cathode chamber. The COD concentration of the influent was gradually increased from 2500 to $4000,5000,6000$, and $6500 \mathrm{mg} / \mathrm{L}$, and the corresponding ammonia nitrogen concentrations of the influent were $60,80,120$, and $180 \mathrm{mg} / \mathrm{L}$.

Table 1. The trace element of nutrient solution

\begin{tabular}{|c|c|c|}
\hline Number & Composition & Amount (g/L) \\
\hline \multirow{4}{*}{$\begin{array}{c}\text { Nutrient } \\
\text { solution 1 }\end{array}$} & EDTA & 15.00 \\
\cline { 2 - 3 } & $\mathrm{ZnSO}_{4} \cdot 7 \mathrm{H}_{2} \mathrm{O}$ & 0.42 \\
\cline { 2 - 3 } & $\mathrm{CuCl}_{2} \cdot 2 \mathrm{H}_{2} \mathrm{O}$ & 0.17 \\
\cline { 2 - 3 } & $\mathrm{NiSO}_{4} \cdot 6 \mathrm{H}_{2} \mathrm{O}$ & 0.21 \\
\cline { 2 - 3 } & $\mathrm{H}_{3} \mathrm{BO}_{3}$ & 0.014 \\
\cline { 2 - 3 } & $\mathrm{CoSO}_{4} \cdot 7 \mathrm{H}_{2} \mathrm{O}$ & 0.28 \\
\cline { 2 - 3 } & $\mathrm{MnSO}_{4} \cdot \mathrm{H}_{2} \mathrm{O}$ & 0.85 \\
\cline { 2 - 3 } & $(\mathrm{NH} 4)_{2} \mathrm{MoO}_{4}$ & 0.20 \\
\hline \multirow{4}{*}{$\begin{array}{c}\text { Nutrient } \\
\text { solution 2 }\end{array}$} & $\mathrm{EDTA}_{4}$ & 15.00 \\
\cline { 2 - 3 } & $\mathrm{FeSO}_{4} \cdot 7 \mathrm{H}_{2} \mathrm{O}$ & 5.00 \\
\hline
\end{tabular}

\section{Results}

\subsection{Changes in sludge}

Initially, the color of the sludge in the reactor appeared yellow-brown. With the continuous adaptation to the conditions of the MFC reactor, the sludge in the reactor gradually turned yellow and then white, and the water kinematic condition became viscous. When the concentration of COD in the influent was $5000 \mathrm{mg} / \mathrm{L}$ (aerobic influent $2300 \mathrm{mg} / \mathrm{L}$ ) and the influent $\mathrm{NH}_{4}{ }^{-}-\mathrm{N}$ concentration was $125 \mathrm{mg} / \mathrm{L}$ (aerobic influent $31.2 \mathrm{mg} / \mathrm{L}$ ), granular sludge began to appear in the reactor. After 20 days, the volume of granular sludge gradually increased, and due to the formation of an anoxic environment inside the particles, most of the particles began to crack down from the center. After the reactor was operated for 60 days, as the continuous increase of the ammonia nitrogen concentration in the aerobic influent, the sludge color in the aerobic chamber gradually changed from white to orange and then the AGS gradually cracked and disappeared.

From the sludge concentration change curve (Fig.1), it can be seen that due to the small proportion of granular sludge in the aerobic area of the cathode in the total sludge, the amount of sludge did not change much after the formation of granular sludge, but the MLVSS still kept above $5 \mathrm{~g} / \mathrm{L}$.

\subsection{Changes of content in SMP, LB-EPS and TB- EPS}

Extracellular polymers (EPS) play a key role in particle formation and stabilization [11]. In order to investigate the changes of EPS content during the formation of granular sludge, the polysaccharides (PS) and proteins (PN) in SMP, LB-EPS and TB-EPS of aerobic zone sludge were measured and analyzed. The PN contained more hydrophobic amino acids (positive functional groups). A higher PN can neutralize the negative charge on the sludge surface, which is conductive to sludge aggregation. The PS contains many carboxyl groups (sub-functional groups) with hydrophilic $(\mathrm{COOH})$. Therefore, in general, the higher the PN/PS value, the stronger the hydrophobicity [12]. According to thermodynamic theory, the higher the hydrophobicity of the cell surface, the lower the Gibbs free energy, which can promote the interaction between cells and facilitate the flocculation of sludge.
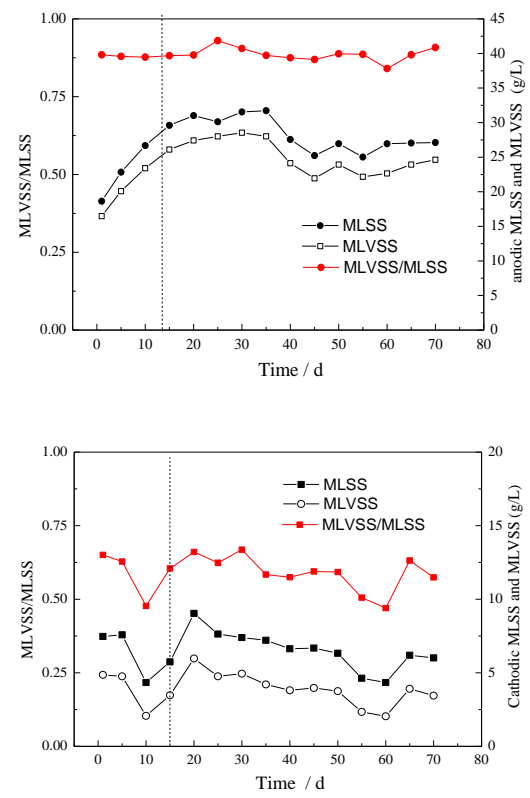

Fig.1. Changes in MLSS and MLVSS
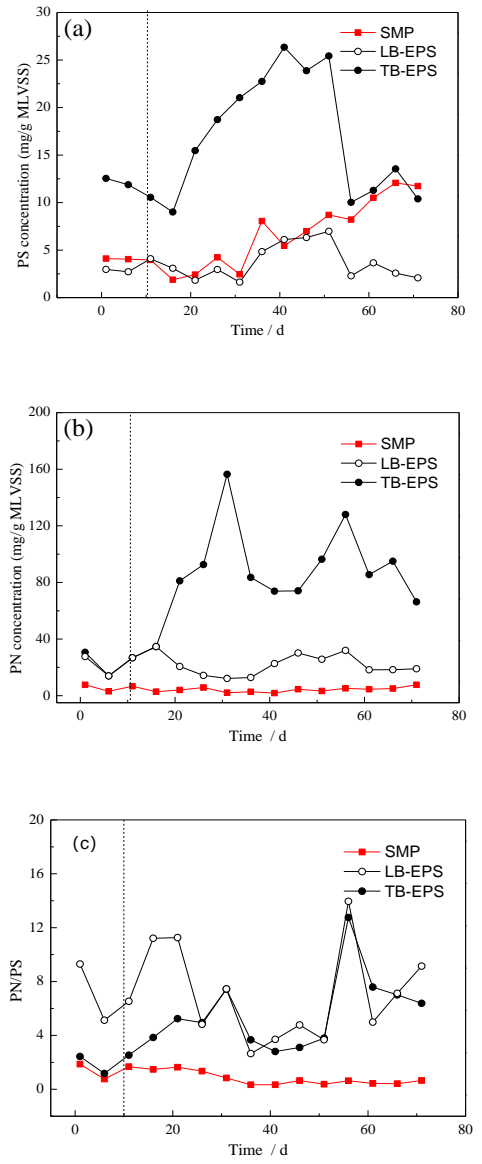

Fig. 2. Changes of content in SMP, LB-EPS and TB-EPS 
From Fig. 2 that in the initial stage of the formation of AGS, the content of TB-EPS changed significantly. The PS, PN and the PN/PS ratio of TB-EPS showed a gradually increasing trend. Reports suggest that the sludge with best settlement ability has the highest TB-EPS content [13]. At 60 days, AGS cracked to a maximal extrnd, and the PS concentration in TB-EPS dropped sharply, from 25.43 $\mathrm{mg} / \mathrm{g}$ MLVSS to $10.03 \mathrm{mg} / \mathrm{g}$ MLVSS, but the PN/PS also increased, from 3.10 to 12.75 . The second time of the increase in PN/PS may be due to the faster decline in PS than PN, which led to an increase in the PN /PS ratio in the short term. Moreover, throughout the process, the content of LB-EPS did not change much, and as the concentration of organic matter in the water increased, the concentration of SMP continued to increase.

\subsection{COD removal}

The removal of COD are shown in Fig.3. Initially, the influent COD concentration was gradually increasing from 2500 to $4000 \mathrm{mg} / \mathrm{L}$, the corresponding effluent of the anode was $1845.9 \mathrm{mg} / \mathrm{L}$, corresponding to a removal efficiency of $35.65 \%$. With increase of influent COD concentration from 5000 to $6500 \mathrm{mg} / \mathrm{L}$, the COD removal efficiency of the anode was gradually stabilized, and remained at about $50 \%$ after 15 days of operation. The effluent of the anode was directly used as the cathodic influent. During the entire operation, the cathode COD removal efficiency was almost maintained above $90 \%$, and the total COD removal efficiency of the MFC system was over $94.46 \%$. It shows that AGS has a strong ability to degrade organic matter.
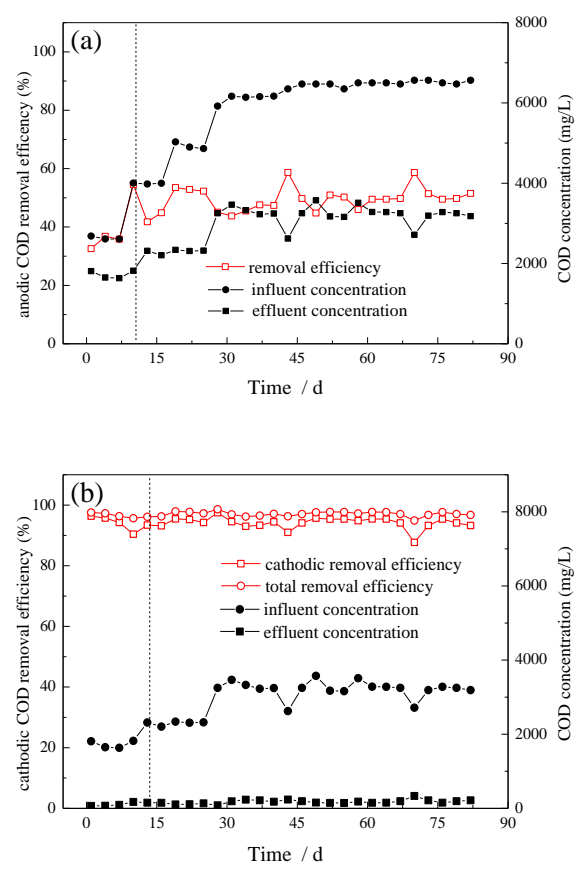

Fig. 3. Changes of COD in anode and cathode

\subsection{Removal of NH4+-N, nitrate and nitrite}

The removal efficiency of AGS on $\mathrm{NH}_{4}{ }^{+}-\mathrm{N}$ and the generation of nitrate and nitrite are shown in Fig.4. Initially, the average $\mathrm{NH}_{4}{ }^{+}-\mathrm{N}$ removal efficiency of anode effluents was $76.17 \%$. The relatively high ammonia removal efficiency could be due to the complex biological system, which consisted of organic degradation, denitrification and bioelectrochemical denitrification [14]. With the continuous increase of the influent $\mathrm{NH}_{4}{ }^{+}-\mathrm{N}$ concentration, the anode $\mathrm{NH}_{4}{ }^{+}-\mathrm{N}$ removal efficiency declined. When the influent $\mathrm{NH}_{4}{ }^{+}-\mathrm{N}$ concentration increased to $180 \mathrm{mg} / \mathrm{L}$, the average anode $\mathrm{NH}_{4}{ }^{+}-\mathrm{N}$ concentration was $92.72 \mathrm{mg} / \mathrm{L}$, and the removal efficiency was $49.84 \%$. At this time, the cathode $\mathrm{NH}_{4}{ }^{+}-\mathrm{N}$ effluent concentration increased from the initial 0.97 to $13.12 \mathrm{mg} / \mathrm{L}$, the corresponding removal efficiency decreased from 99.11 to $87.11 \%$. However, the $\mathrm{NH}_{4}{ }^{+}-\mathrm{N}$ removal efficiency of the MFC system has always remained above $93.03 \%$. This is explained by the AGS which might be enriched by a large number of slowgrowing nitrifying bacteria, so that the system still has a good nitrification effect at a higher $\mathrm{NH}_{4}{ }^{+}-\mathrm{N}$ load.
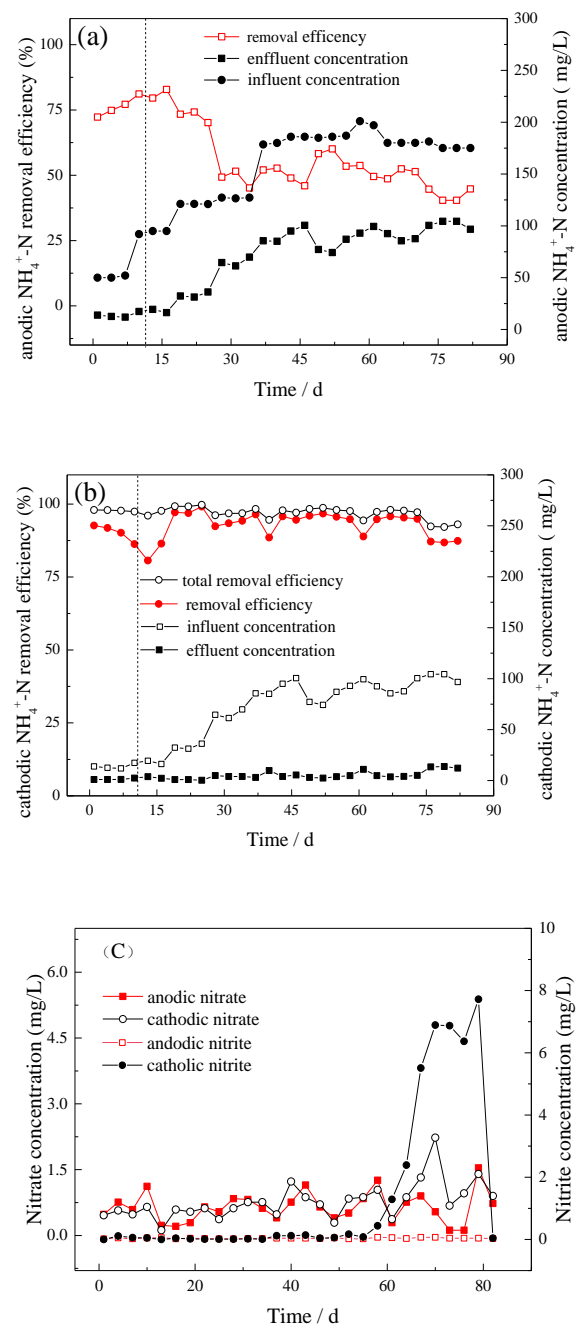

Fig. 4. Changes of $\mathrm{NH}_{4}{ }^{+}-\mathrm{N}$, nitrate and nitrite concentration in anode and cathode

The production of nitrate and nitrite indicates that a nitrification reaction occurred in the anode. Due to the increase of $\mathrm{NH}_{4}{ }^{+}-\mathrm{N}$ concentration in the influent at a later stage, on the 60th day, the cathodic nitrate increased from 0.44 to $7.72 \mathrm{mg} / \mathrm{L}$, and the nitrite concentration slightly increased from 0.02 to $0.07 \mathrm{mg} / \mathrm{L}$. The accumulation of 
nitrate and nitrite may be the main reason for the subsequent cracking of AGS .

\subsection{Electricity generation}

In the early stage of the formation of AGS, the power generation of the system gradually decreased (Fig.5). This may be due to the competition between electrictyproducing bacteria and the methanogens in the initial stage of startup, which caused the system to generate unstable power. With the continuous increase of organic matter and ammonium chloride in the influent, the power generation increased from 150 to $350 \mathrm{mV}$. However, at a later period, with the cracking of AGS, the power generation also gradually decreased, indicating that the formation of AGS has a positive correlation with power generation.

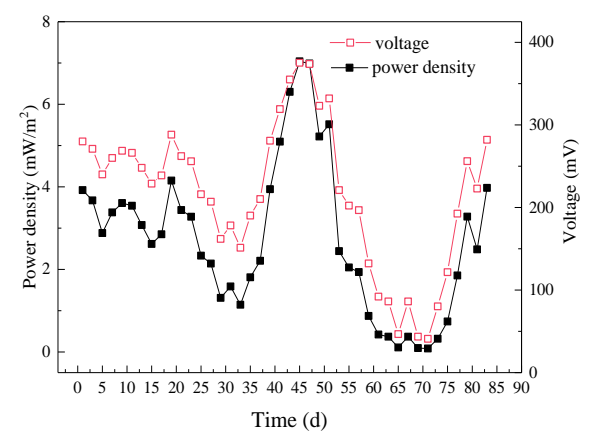

Fig. 5. Voltage and power output

\section{Conclusions}

The formation of aerobic granular sludge was successfully maintained in the continuous flow MFC biocathode, and TB-EPS changed significantly during the formation of AGS. During the entire cultivation process, the MFC system showed a good removal of COD and ammonia nitrogen, with an average removal efficiency of $94.13 \%$ and $96.98 \%$, respectively. The continuous increase of $\mathrm{NH}_{4}{ }^{+}-\mathrm{N}$ concentration at a later operation period resulted in the continuous accumulation of nitrate and nitrite, which may be the main cause of AGS cracking. The electricity generation results showed that the formation of AGS has a positive correlation with the generation of electricity.

This study was supported by Grants from the township sewage treatment technology integration and demonstration project (2017SZ0180) of Sichuan Provincial Bureau of Environmental Protection.

\section{References}

1. D.Wei, L. Shi, T. Yan, G. Zhang, Y. Wang, B. Du, Aerobic granules formation and simultaneous nitrogen and phosphorus removal treating high strength ammonia wastewater in sequencing batch reactor. Bioresource Technol. 2014, 171, 211-6.

2. B. Long, C. Z. Yang, W. H. Pu, J. K. Yang, G. S. Jiang, J. F. Dan, C. Y. Li, F. B. Liu, Rapid cultivation of aerobic granular sludge in a pilot scale sequencing batch reactor. Bioresource Technol. 2014, 166, 57-63.

3. M. K. H. Winkler,C.Meunier, O.Henriet, J.Mahillon, M. E.Suárez-Ojeda, G. Del Moro, M. De Sanctis, C. Di Iaconi, D. G. Weissbrodt, An integrative review of granular sludge for the biological removal of nutrients and recalcitrant organic matter from wastewater. Chem. Eng. J. 2018, 336, 489-502.

4. Y. Liu, Z. Liu, F. Wang, Y. Chen, P.Kuschk, X.Wang, Regulation of aerobic granular s ludge reformulation after granular sludge broken: Effect of poly aluminum chloride (PAC). Bioresource Technol. 2014, 158, 201208.

5. R. D. G. Franca, H. M. Pinheiro, M. C. M. van Loosdrecht, N. D. Lourenco, Stability of aerobic granules during long-term bioreactor operation. Biotechnol. Adv. 2018, 36, 228-246.

6. X. Xin, H. Lu, L. Yao, et al. Rapid Formation of Aerobic Granular Sludge and Its Mechanism in a Continuous-Flow Bioreactor[J]. Appl. Biochem. Biotech., 2016, 181(1).

7. H. Liu, B. E. Logan. Electricity generation using an air-cathode single chamber microbial fuel cell in the presence and absence of a proton exchange membrane[J].Environ. Sci. Technol. 2004, 38(14), 4040 .

8. D. J. Lee, Y. Y. Chen, K. Y. Show, et al. Advances in aerobic granule formation and granule stability in the course of storage and reactor operation $[\mathrm{J}]$. Biotechnol. Adv. 2010, 28(6):919-934.

9. P. Yang, T. Chen, H. Q. Li. Aerobic granular sludge stabilization in biocathode chamber of newly constructed continue flow microbial fuel cell system treating synthetic and pharmaceutical wastewater[J]. Desalin. Water Treat. 2014, 57(8):1-10.

10. J. Huang, P. Yang, Y. Guo, K. Zhang, Electricity generation during wastewater treatment: An approach using an AFB-MFC for alcohol distillery wastewater. Desalination 2011, 276, 373.

11. T. Seviour, Z. Yuan, M C M V Loosdrecht, et al. Aerobic sludge granulation: A tale of two polysaccharides?[J]. Water Research (Oxford) 2012, 46(15).

12. Y. Gao, S. Liu, Q. Cai, H. Li, P. Yang, Effects of Chloride Ion on Performance and Microbial Community in an Anaerobic Fluidized Bed Microbial Fuel Cell. Environ. Eng. Sci. 2019, 36(9), 1214-1223.

13. H. Chen, S.i Zhou, T. Li, Impact of extracellular polymeric substances on the settlement ability of aerobic granular sludge, Environ. Technol. 2010, 31(14), 1601-1612.

14. S. Liu, L. Li, H. Li, H. Wang, P. Yang, Study on ammonium and organics removal combined with electricity generation in a continuous flow microbial fuel cell, Bioresource Technol. 2017, 243, 1087- 1096. 